\title{
Directions of scientific literature in knowledge management from the perspective of their relationships with innovation, information and technology management
}

\author{
Rumos da produção científica em gestão do conhecimento \\ sob a ótica de seus relacionamentos com a \\ gestão da inovação, da informação \\ e da tecnologia
}

Ligia Maria Moura MADEIRA'

Thais Elaine VICK²

Marcelo Seido NAGANO 3

\begin{abstract}
Given the establishment of new journals as a way to fill in gaps and further studies in the area of Knowledge Management and the impact Knowledge Management has had for two decades as a tool for competitive advantage, the aim of the study was to point out tendencies and discuss academic production in Knowledge Management over the years. As the focus of discussion, the article analyzes the relationship of Knowledge Management between Innovation Management, Technology Management and Information Management. The source material for mapping academic output was ten international journals, which were selected from 2006 to 2012, obtaining an initial sample of 2900 papers. The systematic search was conducted to identify which relationships are more predominant in the journals selected. Through the analysis of relationships in publications within the time interval established, it was found that the relationship between Knowledge Management and Technology Management appears much more frequently in all publications over the years. The relationship between Knowledge Management and Technology Management decreased significantly in recent years. In contrast, there was an increase in papers discussing Knowledge Management and Innovation Management.
\end{abstract}

Keywords: Information management. Innovation management. Knowledge management. Technology management.

\section{Resumo}

Dada a criação de novos periódicos como forma de suprir lacunas e ampliar estudos no campo da Gestão do Conhecimento, bem como o impacto que esta vem criando há duas décadas como ferramenta de vantagem competitiva, o escopo do trabalho reside em apontar tendências e discutir como se encontra a produção acadêmica em Gestão do Conhecimento. Como foco de discussão, analisa-se a Gestão do Conhecimento a partir de seus relacionamentos com a Gestão da Inovação, Gestão da Tecnologia e com a Gestão da Informação.

\footnotetext{
1 Mestranda, Universidade de São Paulo, Escola de Engenharia de São Carlos, Programa de Pós-Graduação em Engenharia de Produção. Av. Trabalhador Sãocarlense, 400, 13566-590, São Carlos, SP, Brasil. Correspondence to/Correspondência para: L.M.M. MADEIRA. E-mail: <ligiamariamadeira@yahoo.com.br>. 2 Doutoranda, Universidade de São Paulo, Escola de Engenharia de São Carlos, Programa de Pós-Graduaçãoem Engenharia de Produção. São Carlos, SP, Brasil.

3 Professor Doutor, Universidade de São Paulo, Escola de Engenharia de São Carlos, Departamento de Engenharia de Produção. São Carlos, SP, Brasil. Received on 9/13/2012, resubmetted on 11/9/2012 and approved for publication on 12/6/2012.
} 
Tomando como fonte documental para um mapeamento da produção acadêmica, foram selecionados 10 periódicos internacionais no período que compreende os anos de 2006 a 2012, com uma amostra inicial de 2900 artigos. Fundamentando-se na busca sistemática, objetivou-se identificar quais relacionamentos campeiam com maior ênfase nos periódicos escolhidos. Por meio da análise dos relacionamentos pelas publicações no decorrer dos anos, constatou-se que o relacionamento entre a Gestão do Conhecimento e a Gestão da Tecnologia aparece em maior número em todos os anos de publicações. Percebeu-se ainda que o relacionamento entre Gestão do Conhecimento e Gestão da Informação diminuiu significativamente nos últimos anos. Em contrapartida, houveum crescimento de trabalhos que envolvem a Gestão do Conhecimento e a Gestão da Inovação.

Palavras-chave: Gestão da informação. Gestão da inovação. Gestão do conhecimento. Gestão da tecnologia.

\section{Introduction}

Knowledge Management is a field of management that assists in the processes of knowledge and creation, relating mainly to information, technology and innovation management, as well as the competence management within organizations with an emphasis on the absorption of tacit knowledge. Furthermore, Knowledge Management, as a field, is connected to five sub-areas related to strategic relationships, as follows: Innovation Management, Technology Management, Production Information Management, Information System Management, and Decision Support Systems. For this study, we selected three areas related to Knowledge Management: Innovation Management, Technology Management, and Information Management.

Based on these fields of management, the aim of the paper was to conduct a systematic review of the literature, not in order to characterize it, but rather trying to point out trends in the current state of research in Knowledge Management and its sub-areas, with emphasis on the three previously mentioned relationships that receive more emphasis in organizational processes at present.

Thus, we first define our scope of discussion by reviewing the three relationships in the literature. Then we present the data obtained from a systematic search, discuss the results, and suggest further research.

\section{Innovation management in the context of knowledge management}

The theme of innovation has been gaining space since mid-2000. Innovation is conceptualized as a process of structural and mental knowledge and consequently, is defined as a process where knowledge is absorbed, assimilated, shared and used with the intention of creating new knowledge (Harkema; Browaeys, 2001).

Innovation Management is a field that deals with questions about how the process of innovation must be managed effectively, a field that has gained much attention from researchers. However, according to Asimakou (2009), theorists in Innovation Management are late to "embrace" the technical progress in the field of Knowledge Management. Not only the literature in innovation, but also practice, should gain understanding of its limitations and weaknesses to embrace perceptions due to recent studies in the field of Knowledge Management. Knowledge is an asset, as well as land, capital and labor that can be objectified and transferable within and between organizations. However, the assumptions that form the theory and practice of innovation management within the context of knowledge follow the positivist thought, resulting in a rigid and decontextualized image of knowledge which leads to the practitioners of Knowledge Management to see it as an improved version ofTechnology Management.

According to Du Plessis (2007), Knowledge Management helps identify gaps in the knowledge base, providing processes that fill in these gaps and assist innovation.

Both Knowledge Management and Innovation Management represent areas of management that initially seemed to reside in separate spheres with little or no impact on one another (Goh, 2005). Nevertheless, this statement does not express the true reality in practice, in which Knowledge Management acts to improve the strategy of continuous innovation, making the most efficient use of knowledge to create, improve, streamline and increase the effective cost of innovations to remain competitive.

In this respect, a new denomination for Management of Knowledge Innovation (KI) was 
established: Management of Knowledge Innovation, which was defined as: creation, evolution, exchange and application of new ideas into marketable goods and services, leading to the company's success, to the vitality of the economy and the advancement of society (Goh, 2005). Convergence between the two management areas brings strategic advantages to improve organizational performance.

In the context of Research and Development (R\&D), the process of creation and transfer of knowledge can be effectively observed. Recently the R\&D and Innovation Management have been explicitly connected to Knowledge Management and Organizational Learning, in which R\&D and innovative activities are seen as a complex search, a learning process and problem solving processes which are based on existing knowledge, but also create new knowledge (Brännback, 2003). Therefore, the context may differentiate not only the processes of knowledge creation but value creation, which will influence the structure and industrial markets.

Because of these contextual differences, the high-tech companies, for example, play an important role in creating knowledge networks (Valkokari et al., 2012). In this regard, a school of thought called dynamic capability, which refers to the action and the ability to renew competence in a changing environment, creates new organizational logic, which is part of the fundamental nature of knowledge creation. Dynamic capability became the basis for the study of Innovation Management within the context of knowledge in the growing number of high-tech industries (Nielsen, 2006).

\section{Technology management in the context of knowledge management}

In recent decades, a series of questions and criticisms have arisen concerning the added value and effectiveness of technologies and solutions for Knowledge Management (Rizzietal., 2009).

To manage organizational knowledge, the organization needs to train and redefine the interactions among people, technology and techniques. The tools in Knowledge Management can be technical and technological. The use of these techniques in the context of Knowledge Management is extremely important to increase knowledge. As examples of these techniques, the following can be mentioned: brainstorming, communities of practice (CoPS), face to face interactions, post-project revisions, recruitment, activities involving a mentor, learning and training.

Technologies rely on information technology infrastructure; they consist of a combination of hardware and software technologies. Organizations will only adopt technologies for Knowledge Management if there are benefits in terms of business that can be extended throughout the organization. Therefore, it is extremely important that technology developers for Knowledge Management fully understand the processes and working methods of the end users of these technologies. Although technologies are effective tools for searching, storing, manipulating and sharing large amount of information per unit of time, assigning a meaning to information depends on people. To sustain long-term competitive advantages in the organization, it needs to create an inter-relationship between technological and social systems.

A second approach can be taken with regard to the technological systems. Centralized Knowledge Management Systems have some inconveniences; the inflexible structures and centralized control may decrease flexibility and availability of knowledge through processes that standardize knowledge and information and remove context. The approach here is to include the technology known as Peer-to-Peer (P2P), which promises to overcome the inconveniences supporting interaction and knowledge sharing in different contexts (Gupta; Bostrom, 2006; Accorsi; Costa, 2008). The Ba (knowledge sharing) is the context that allows the interaction between this technology and Knowledge Management. The P2P joins the concept of $\mathrm{Ba}$ and gives rise to a new entity called connecting $\mathrm{Ba}$, in which socialization and internalization of knowledge take place.

The Knowledge Management tools are increasingly improving and diversifying, whether technically or technologically, as well as providing support to the process. In the literature, several technological solutions have been proposed to facilitate the processes of Knowledge Management. According Accorsi and Costa (2008), one of the most widely used technological constructs specifically designed for Knowledge Management is the Knowledge Management System 
(KMS); however, its structural nature makes knowledge and information standardized, removing them from context. The KMS is often defined as an expensive structure that demands a great organizational effort to function effectively. A few examples are: document repositories, database expertise, mailing lists etc.

Another aspect to be discussed, according to Venters (2010), is that there is a range of technologies that have been closely aligned with the initiatives of Knowledge Management which can have two definitions: the first focuses on knowledge management supporting individual learning and direct communication (i.e., decision support systems, intranets, videoconferences). The second focuses on the emergent and collective nature of knowledge sharing, in which socio-psychological factors are important in determining the success of Knowledge Management Technology (KMT) and focus on the technology of social networking.

Thus, new knowledge is developed in the organization where knowledge workers interact with each other using shared digital artifacts. Exchanges that occur between the individual cognitive and social systems are the basis for the development of new knowledge. It is specifically in the processes of socialization and internalization that knowledge transfer occurs in this context.

\section{Information management in the context of knowledge management}

Competitiveness has introduced new behaviors leading companies to an uncomfortable situation that are often not capable of adapting to environmental demands (Hayes; Wheelwright, 1984). Thus, Information and Knowledge Management in organizations are given more importance than the search for the most appropriate ways to meet current demands (Goh, 2005).

Information Management tries to explain the behavior of the organization by examining information flows around it. Previous studies such as the one by Chou et al. (2007) showed that the ability to understand information processing is important because it facilitates the activities of knowledge creation and thus, affects strategic actions.
Gold etal.(2001)suggest that a key to understanding the success and failure of knowledge management is the identification and assessment of preconditions, such as the information process capabilities, that are necessary for the effort to flourish. However, few studies report empirical tests of the connections between capabilities of Information Management and its effect to the creation of effective knowledge.

Therefore, we recognized the need to further understand how new knowledge are actually developed in the midst of organizational processes. The process of knowledge creation is complex, dynamic but not linear and its characteristics are not always explicit. This fact makes the challenge of understanding it even greater (Leonard-Barton; Sensiper, 1998; Nonaka et al., 1998). The complexity that is currently a characteristic of organizations makes the demand for skills related to information management a need for an overall good performance of Knowledge Management. The lack of control of information prevents the synergy between the different members of the organization (Cândido et al., 2005).

The idea of strategic resource in organizations has required information to be managed as the financial and human resources are managed. Initially called Information Resource Management, Information Management represents the entire value chain of information, in other words, it must include the definition of information needs, collection, storage, distribution and retrieval for subsequent use of the information (Cianconi, 2003).

Information processing generates more information which, in turn, generates knowledge that subsidizes the strategy providing the basis for action and provides the necessary feedback to start the process. Thus, managing information should be seen as the management of a network of processes that acquire, create, organize, distribute, and use the information in a continuous cycle (Choo, 1998; Popadiuk; Choo, 2006).

Information management within the context of Knowledge Management is therefore subjected to the following assumptions: the creation of meaning for the understanding of its operation environment; development of knowledge to fill in the gaps of knowledge and develop new competences; decision making to choose course of 
action. Generating and processing information is shaped by the culture and specification of rules, routines and roles. Information and meanings are forged in the thoughts, feelings, and actions of individuals in a cyclical process (Silveira; Oddone, 2007).

\section{Methods}

According to Silva and Menezes (2001), research can be classified as quantitative and exploratory. The systematic survey of the literature occurred through an initial search in databases (Scientific Eletronic Library Online (SciELO), Google Scholar, Web Qualis of the Coordenação de Aperfeiçoamento de Pessoal de Nível Superior (Capes, Coordination for the Improvement of Higher Education Personnel)) by combining keywords to research journals related to the topic in the period comprising the years 2006-2012.

A total of 10 journal titles were selected which contained articles from the international literature with $A$ and $B$ ratings according to Qualis Capes and rated as $C$ in the field of Knowledge Management. An initial sample of approximately 2,900 articles was obtained which addressed one of the major areas in the study: Knowledge Management, Information Management, Innovation Management and Technology Management.

Of 2,900 studies, only 295 met the requirements established for the review since these selected articles dealt with at least one of the relationships proposed for our discussion: relationship between Knowledge Management and Technology Management, between Knowledge Management and Information Management or between Knowledge Management and Innovation Management.

\section{Results}

\section{Analysis of relationships according to the number of publications over the years}

To search for the articles containing the proposed relationships, a seven-year period, extending from 2006 to 2012, was chosen to allow greater comprehensiveness of the subject. The broadness of each relationship was addressed quantitatively by adding up the number of articles selected for each relation and the corresponding year. Thus, Figure 1 illustrates quantitatively the observations made by systematic reading. In accordance with Figure 1, Table 1 shows the specific distribution of the 295 articles analyzed by year of publication.

In the period that encompassed the years 2009 to 2012, the decrease in the number of published papers that deal with the relationship between Knowledge Management and Information Management in international journals analyzed within the seven-year period is clear. That is due in large part by the emphasis that was given to this relationship, particularly in the years prior to 2006, with the "Westernization" of the Japanese theory of knowledge creation and the exhaustive search

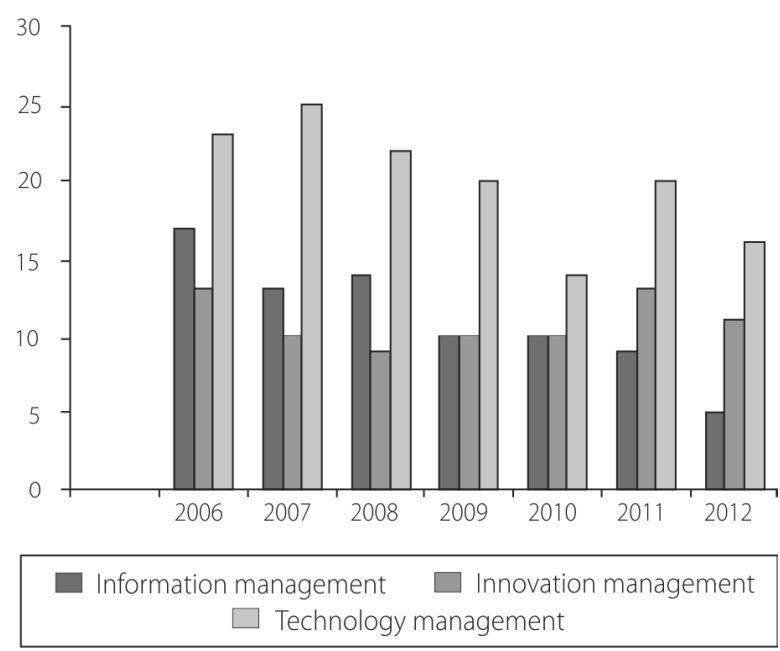

Figure 1. Analysis of the relationships according to the number of publications over the years.

Source: Developed by the authors.

Table 1. Specific distributions of the 295 articles analyzed per year of publication.

\begin{tabular}{cccccccc}
\hline \multicolumn{2}{c}{ KM InfoM } & & \multicolumn{2}{c}{ KM InnovM } & & \multicolumn{2}{c}{ KM TecM } \\
\cline { 1 - 2 } \cline { 7 - 8 } \cline { 7 - 8 } Year & Total & & Year & Total & & Year & Total \\
\hline 2006 & 17 & & 2006 & 13 & & 2006 & 23 \\
2007 & 13 & & 2007 & 10 & & 2007 & 25 \\
2008 & 14 & & 2008 & 9 & & 2008 & 22 \\
2009 & 10 & & 2009 & 10 & & 2009 & 20 \\
2010 & 10 & & 2010 & 10 & & 2010 & 14 \\
2011 & 9 & & 2011 & 13 & & 2011 & 20 \\
2012 & 5 & & 2012 & 12 & & 2012 & 16 \\
\hline
\end{tabular}

KM: Kowedge Management; InfoM: Information Management; InnovM: Innovation Management; TeaM: Technology Management.

Source: Developed by the authors. 
of researchers to explain the phenomenon of transforming information into knowledge and information knowledge as well as the challenges to record it and make it available.

As the data show from 2010 to 2012, studies in international journals have shown increasing interest to the field of innovation and technology. The focus of studies on the contributions of Knowledge Management in processes of technological innovation appeared more frequently throughout the study period.

The relationship between Knowledge Management and Technology Management was responsible for most publications from 2006 to 2012, a result that is due to the development of new supporting tools for the development of Knowledge Management. Considering that the year of 2012 was analyzed up to the middle of the last semester, the call for papers was analyzed until the end of this year. Most call for papers suggest studies on smart technologies and new strategies in Knowledge Management. It is believed, therefore, that the relationship between Knowledge Management and Technology Management will appear with greater frequency in the following year in the journals analyzed, followed by the relationship between Knowledge Management and Innovation Management.

With regard to relationships, the following was found:

- Knowledge Management and Technology Management: an important role was found between the techniques and technologies to assist and facilitate the working process of Knowledge Management over the period. This result is largely due to the diversification and improvement of these instruments, as well as the influence of digital artifacts in the processes of knowledge conversion. There is a trend to maintain this topic within its discussion space, since there is a continuous creation of new technologies, thus the possibilities of research are never exhausted.

- Knowledge Management and Innovation Management: on the other hand, one cannot observe the same interest in innovation. Innovation processes have gained increasing significance since 2006, but this is connected to the economic field; when it comes to Knowledge Management, the relationship with innovation changes due to the lack of discernment of researchers and experts in relation to the understanding that one cannot exist without the other. Although this is well known, between 2011 and 2012, further increase concerning Innovation Management occurred, which was confirmed in the literature by networks creating knowledge and the dynamic capacity to renew competences in a changing environment.

- Knowledge Management and Information Management: the significant decrease in studies on this relationship is due in part to the current phenomena related to Technology Management, which act as a contribution to Knowledge Management, meeting the most urgent needs of organizations that have recently become aware of this management model. However, it is noteworthy that effective Technology Management that supports Knowledge Management can only occur from the assessment of preconditions, which are nothing more than the capabilities of Information Management. Another aspect that should be mentioned is the internationalization of economy which considerably influenced studies and research on the topic of Competitive Intelligence that now competes for space with Information Management.

\section{Proportions of publications in the international journals selected}

Ten international journals were selected, most of which are ranked as $A$ and $B$, with only one title rated as $C$. With the purpose of explaining the percentage contribution of each title, Figure 2 shows the results obtained.

Overall, considering the time limit between 2006 and 2012, the sample pre-selected approximately 2,900 articles. However, after reviewing the abstracts, 295 articles were selected for the study.

The observed percentages were obtained through a relationship that encompasses each individual value of the title in addition to the three relationships (Knowledge Management and Information Management, Knowledge Management and Innovation Management, Knowledge Management and Technology Management) to every year and in relation to the total number of existing articles within the deadline. For example, in the International Journal of Information Management, the number of 


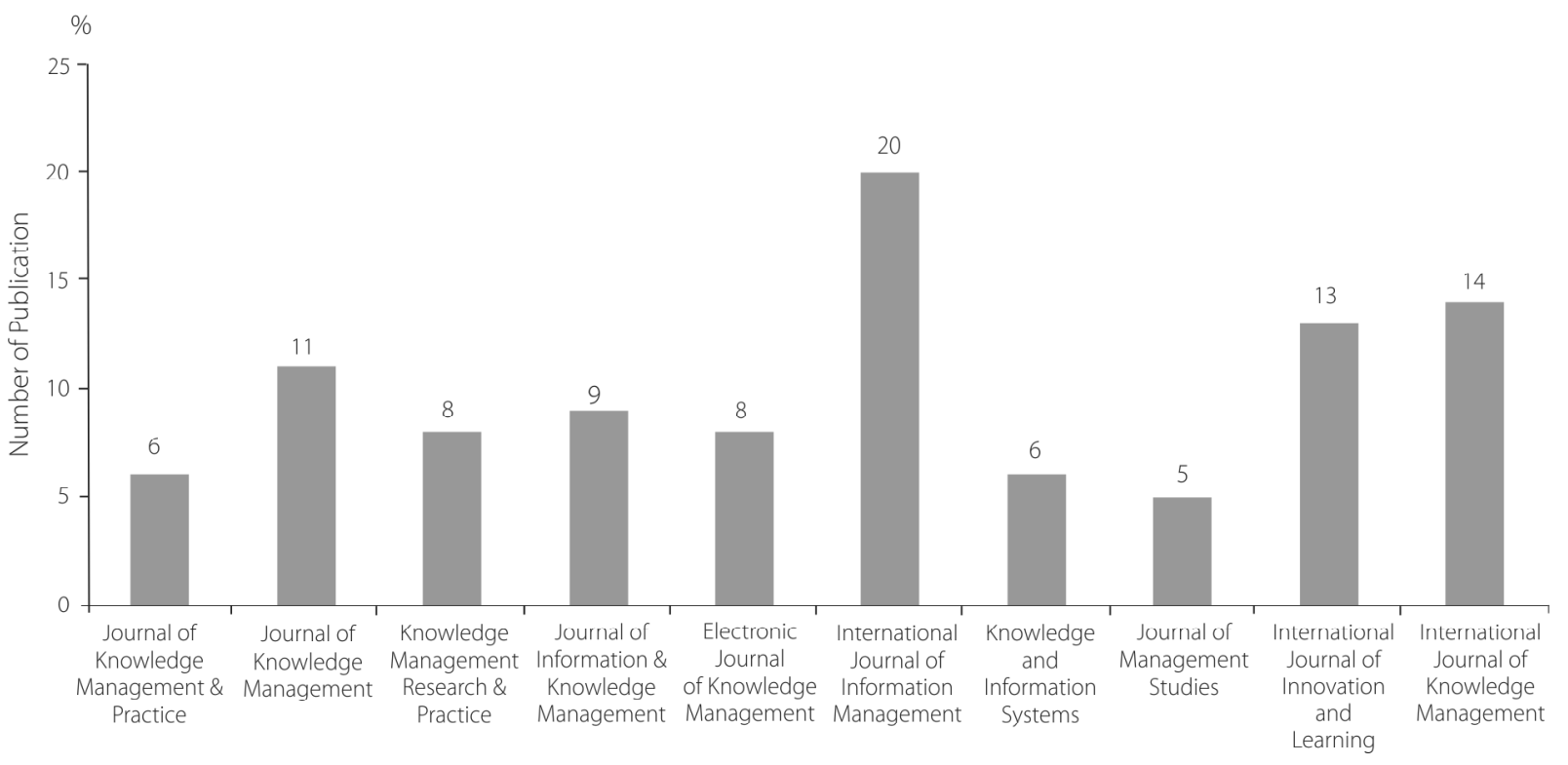

Figure 2. Proportions of publications in the international journals selected.

Source: Developed by the authors.

articles selected between the three relationships and over all the years consisted of $20 \%$ of the existing articles in this journal title within the deadline.

As in the literature surveyed, the articles analyzed presented the three relationships with the following emphases:

- Relationship of Knowledge Management and Innovation Management in the innovation process of high-tech industries, as suggested by Goh (2005) and Nielsen (2006);

- New technologies that have been closely connected to Technology Management and Knowledge Management initiatives, foreseen by Venters (2010);

- Preconditions of Knowledge Management related to the capabilities of Information Management and examined by Gold et al. (2001).

\section{Final Considerations}

By observing the relationships analyzed by number of publications over the years, as well as the proportion of publications in the international journals selected, it was found that the relationship between Knowledge Management and Technology Management appears in larger numbers throughout the years of publications. It is noteworthy that the relationship between Knowledge Management and Information Management appeared frequently from 2006 to 2008, but decreased significantly in recent years, as of 2009. In contrast, there was an increase in studies involving Knowledge Management and Innovation Management in 2011 and 2012.

Although the emphasis given to the three relationships due to overwhelming number of organizational processes, it is noteworthy that in the international literature (selected due to the higher level of significance), despite Innovation Management being widely studied as of 2006 when it is related to Knowledge Management, a gap in this relationship can be found largely due to innovation always being addressed within the context of the company to obtain higher profit and market margin and not being directed to knowledge processes.

It is expected, as a contribution of the article, that this mapping may serve further research to fill in the gaps of knowledge in areas discussed. The increase in scientific production in Knowledge Management and Innovation Management reflects the current need of researchers who endeavor to understand the phenomena caused by competitiveness increasingly based on individuals and the development of new knowledge and new products/ 
processes. The areas of Technology Management and Information Management are therefore relevant to improve all Knowledge Management processes, acting as supporters and facilitators, as well as transferring and disseminating organizational knowledge. Furthermore, the aim of this survey was to elucidate the importance and benefits of new studies that address the relationship of Knowledge Management with related areas for the evolution of the discipline as a whole.

\section{References}

ACCORSI,F.L.; COSTA, J.P.Peer-to-peer systems consubstantiating the Ba concept. Electronic Journal of Knowledge Management, v.6, n.1, p.1-12, 2008.

ASIMAKOU, T. The knowledge dimension of innovation management. Knowledge Management Research \& Practice, v.7, n. 1, p.82-90, 2009.

BRÄNNBACK, M. R\&D collaboration: role of Ba in knowledge-creating networks. Knowledge Management Research \& Practice, v.1, n.1, p.28-38, 2003.

CÂNDIDO, C.A. et al. Gestão estratégica da informação: semiótica aplicada ao processo de tomada de decisão. Datagramazero: Revista de Ciência da Informação, v.6, n.3, p.1-16, 2005.

$\mathrm{CHOO}, \mathrm{C} . W$. The knowing organization: how organizations use information to construct meaning, create knowledge, and make decisions. New York: Oxford University, 1998.

CHOU, T.C. et al. A path model linking organizational knowledge attributes, information processing capabilities, and perceived usability. Information \& Management, v.44, p.408-417, 2007.

CIANCONI, R.B. Gestão do conhecimento: visão de indivíduos e organizações no Brasil. 2003. Tese (Doutorado) - Instituto Brasileiro de Informação em Ciência e Tecnologia, Brasília, 2003.

DU PLESSIS, M. The role of knowledge management in innovation. Journal of Knowledge Management, v.11, n.4, p.20-29, 2007.

$\mathrm{GOH}$, A.L. Harnessing knowledge for innovation: an integrated management framework. Journal of Knowledge Management, v.9, n.4, p.6-18, 2005.

GOLD, A.H. et al. Knowledge management: an organization capabilities perspective. Journal of Management Information Systems, v.18, n.1, p.185-214, 2001.

GUPTA, S.; BOSTROM, R. Using peer-to-peer technology for collaborative knowledge management: concepts, frameworks and research issues. Knowledge Management Research \& Practice, v.4, n.3, p.187-196, 2006.
Further studies could focus on presenting methodologies applied to the informational phenomena with the purpose of minimizing the existing problems in our so-called Information Society. We suggest further studies on culture and information behavior that are related to Information Science in Organizational Psychology and Sociology of the Company, whose interactions are extremely beneficial for the understanding of these phenomena.

HARKEMA, S.J.; BROWAEYS, M.J. Managing innovation successfully: a complex process. 2001. Available from: <http:// ecsocman.hse.ru/data/601/645/1219/managin_inn.pdf>. Cited: Mar. 5, 2012.

HAYES, R.H.; WHEELWRIGHT, S.C. Restoring our competitive edge: competing through manufacturing. New York: Free, 1984.

LEONARD-BARTON, D.; SENSIPER, S. The role of tacit knowledge in group innovation. California Management Review, v.40, n.3, p.112-127, 1998.

NIELSEN, A.P. Understanding dynamic capabilities through knowledge management. Journal of Knowledge Management, v.10, n.4, p.59-71, 2006.

NONAKA, I.; REINMOELLER, P.; SENOO, D. The ART of knowledge: systems to capitalize on market knowledge. Oxford, v.16, n.6, p.673-684, 1998.

POPADIUK, S.; CHOO, C.W. Innovation and knowledge creation: how are these concepts related? International Journal of Information Management, v.26, p.301-311, 2006.

RIZZI, C.; PONTE, D.; BONIFACIO, M. A new institutional reading of knowledge management technology adoption. Journal of Knowledge Management, v.13, n.4, p.75-85, 2009.

SILVA, E.L.; MENEZES, E.M.Metodologia da pesquisa eelaboração de dissertação. Florianópolis: UFSC, 2001. Disponível em: $<$ http://www.eps.ufsc.br/ppgep.html>. Acesso em: 6 maio 2012.

SILVEIRA, M.M.; ODDONE, N. Information needs and information behavior: concepts and models. Ciência da Informação, v.36, n.1, p.118-127, 2007.

VALKOKARI, K.; PAASI, J.; RANTALA, T. Managing knowledge within networked innovation. Knowledge Management Research \& Practice, v.10, n.1, p.27-40, 2012.

VENTERS, W. Knowledge management technology-in-practice: a social constructionist analysis of the introduction and use of knowledge management systems. Knowledge Management Research \& Practice, v.8, n.2, p.161-172, 2010. 